\title{
The use of the dried blood spot sample in epidemiological studies
}

\author{
S P Parker, W D Cubitt
}

The concept that capillary whole blood, obtained by heel or fingerprick and blotted on to a filter paper (Guthrie card), could be used to screen for metabolic disease in large populations of neonates was introduced in Scotland by Guthrie and Susie in $1963 .{ }^{1}$ Neonatal screening for phenylketonuria became nationwide in 1969/70. Since then, Guthrie card samples from two to nine day old babies have been collected routinely in over 20 countries to screen for phenylketonuria and more recently for congenital hypothyroidism and sickle cell disorders. $^{2-4}$ The detection of markers of disease, such as medium chain acyl CoA dehydrogenase (MCAD deficiency), human chorionic gonadotrophin (hCG) in Down syndrome, and glycated haemoglobin in insulin dependent diabetes, and the estimation of drug levels have been also been investigated..$^{5-8}$ The limitations of sensitivity and specificity when screening such small volumes of blood (equivalent to 5-10 $\mu \mathrm{l}$ ) restricted the use of dried blood spots (DBS) for many years. However, recent advances such as the production of monoclonal antibodies, expression of synthetic proteins, and the introduction of the polymerase chain reaction (PCR) have overcome many of these problems, allowing the potential of a vast bank of stored DBS to be realised by biochemists, geneticists, and microbiologists.

Blood obtained from neonates contains IgG antibodies that are primarily of maternal origin. This has enabled extensive studies to be performed on neonatal DBS to estimate the 2 March 1999

Table 1 Anonymous surveys based on dried blood spot sample testing

\begin{tabular}{llll}
\hline Agent & Country & Assay & Year/reference \\
\hline HIV & USA & ELISA and western blot & $92^{9}$ \\
& Scotland & As above & $94^{10}$ \\
& EPA and western blot & $93^{11}$ \\
& & GPA and western blot & $97^{12}$ \\
& GACPAT and western blot & \\
HTLV-I & England & GPA, ELISA and immunoblot & $95^{13}$ \\
& South Africa & GPA and immunoblot & $96^{14}$ \\
HCV & England & "In house" ELISA, GPA, and RIBA & $97^{15}$ \\
& Pakistan & As above & 98 unpublished \\
& South Africa & As above & 98 unpublished \\
Toxoplasma gondii & England & Latex agglutination test & $92^{16}$ \\
& Denmark & ELISA & $95^{17}$ \\
& Ireland & Latex agglutination test & $98^{18}$ \\
\hline
\end{tabular}

ELISA, enzyme linked immunosorbent assay; GACPAT, IgG capture gelatin particle adherence test; GPA, gelatin particle agglutination; HCV,hepatitis $\mathrm{C}$ virus; HIV, human immunodeficiency virus; HTLV, human T cell leukaemia/lymphoma virus; RIBA, recombinant immunoblot assay. seroprevalence of infections in women of childbearing age (table 1). Similarly, DBS obtained from children and adults have been used for the diagnosis of infections and for sentinel surveys in many parts of the world (tables 2 and 3 ).

In this review we concentrate on the benefits and applications of DBS technology with specific reference to the field of microbiology.

\section{The dried blood spot sample}

Peripheral blood is collected by piercing the skin of either a finger or heel with a Sterilette ${ }^{\mathrm{TM}}$ and blotted onto high quality filter paper, for example a Guthrie card (S\&S 903, Schleicher and Scheull UK). The use of S\&S 2992, Whatman grade 1 or 3 papers has also been reported..$^{53}$ The blood spot should then be allowed to air dry and ideally stored in low gas permeable bags that contain desiccant to reduce humidity. Samples can be tested immediately, stored at ambient temperature even under tropical conditions, ${ }^{54}$ or frozen at $-20^{\circ} \mathrm{C}$, where the level of IgG antibodies may remain stable for several years..$^{55-57}$

Before testing in the laboratory a disc of dried blood typically $3.0-5.5 \mathrm{~mm}$ in diameter, equivalent to $1-4 \mu \mathrm{l}$ of serum, is punched either manually or with an automated machine into the wells of a flat bottomed microtitre plate. The blood is eluted out in phosphate buffered saline containing $0.05 \%$ Tween 80 and $0.005 \%$ sodium azide, overnight at $4^{\circ} \mathrm{C}$ (figs $1-3$ ). The resultant plate containing the eluates forms the "master" from which dilutions can be made for subsequent testing.

\section{Advantages of DBS}

REDUCTION OF RISKS

The collection of capillary blood on filter paper has significant advantages over venepuncture, particularly when bleeding neonates; it is simple to perform, requires minimal training, and does not involve the risks associated with the use and disposal of needles and syringes.

The DBS represents a low infectious hazard as some viruses such as HIV-1 and -2, human $\mathrm{T}$ cell leukaemia/lymphoma virus (HTLV) -I and $-\mathrm{II}$, and hepatitis $\mathrm{C}$ virus (HCV) that are known to be present in serum or plasma lose infectivity owing to disruption of their envelope on drying. ${ }^{58}$ However, virus in high titre may 
Table 2 Dried blood spot sample protocols and sentinel surveys based on the use of blood spots collected on filter paper

\begin{tabular}{|c|c|c|c|c|}
\hline Agent & Study & Assay type & Country of survey & Year/ref \\
\hline \multicolumn{5}{|l|}{ Viral } \\
\hline $\mathrm{HBV}$ and HAV & Prevalence of markers & RIA, RPHA & Saudi Arabia & $78^{19}$ \\
\hline HBV & Epidemiology & RIA & Italy & $81^{20}$ \\
\hline Rubella & & ELISA & Denmark & $81^{21}$ \\
\hline $\mathrm{HBV}$ and HAV & WHO field studies & RIA & Sao Tome & $85^{22}$ \\
\hline \multirow[t]{2}{*}{ Measles } & Vaccine study & HAI & Guinea-Bissau & $94^{23}$ \\
\hline & Vaccine study & ELISA & Italy & $98^{24}$ \\
\hline Measles, mumps and rubella & MMR vaccine study & ELISA & Italy & $\begin{array}{l}94^{25} \\
98^{26}\end{array}$ \\
\hline HAV & Prevalence study & ELISA & Spain & $95^{27}$ \\
\hline \multicolumn{5}{|l|}{ Bacterial } \\
\hline Mycobacterium leprae & Epidemiological study & PA & India & $92^{28}$ \\
\hline \multirow[t]{2}{*}{ Diphtheria and tetanus antitoxin } & $\begin{array}{l}\text { Immunity study and vaccine } \\
\text { monitoring }\end{array}$ & ELISA & Australia & $94^{29}$ \\
\hline & & ToBI & Vietnam & $96^{30}$ \\
\hline \multicolumn{5}{|l|}{ Protozoan } \\
\hline Trypanosoma cruzii & Chagas disease & IFAT, HA, ELISA & Brazil & $90^{31}$ \\
\hline \multicolumn{5}{|l|}{ Helminthic } \\
\hline \multirow[t]{2}{*}{ Echinococcus granulosus } & Hydatidiosis & ELISA & Argentina & $88^{32}$ \\
\hline & & ELISA & Kenya & $93^{33}$ \\
\hline
\end{tabular}

ELISA, enzyme linked immunosorbent assay; GPA, gelatin particle agglutination; HAV, hepatitis A virus; HBV, hepatitis B virus; HIA, haemagglutination inhibition assay; IFAT, immunofluorescence antibody test; PA, particle agglutination; RIA, radioimmunoassay; RPHA, reverse passive haemagglutination; ToBI, toxin binding inhibition test.

remain viable on a surface for several days and hepatitis $\mathrm{B}$ virus (HBV) may remain infectious for at least seven days. ${ }^{59}$

Risks associated with shipping are minimised as DBS cannot leak or be broken in transit and there is no requirement for carriage on dry ice. Handling of potentially infected material is also reduced as the need to centrifuge and separate sera from blood clots is eliminated.

\section{ECONOMIC ADVANTAGES}

Collection and processing of DBS is considerably cheaper than samples collected by venepuncture. Sterilettes are available at a one third of the price of sterile disposable needles and syringes in the United Kingdom..$^{52}$ DBS can be readily shipped in sealed envelopes to reference centres, whereas sera need to be packed in break-proof containers. Transport of frozen sera may require the use of dry ice or liquid nitrogen, requiring further specialised handling and adding considerable weight to the item.

The majority of the diagnostic techniques, for example particle agglutination tests and enzyme immunoassays (EIA) which have been used to screen for antibodies in DBS, are simple and generally require little capital expenditure. The use of the agglutination test is particularly cost-effective as the assay can be performed in the absence of an electricity supply. This is ideally suited to countries with limited health budgets.

\section{SURVEILLANCE}

Large scale epidemiological surveys can be performed rapidly, enabling strategic decisions to be made about targeting at risk populations.

Table 3 Dried blood spot sample based protocols specific for the serodiagnosis of infection

\begin{tabular}{|c|c|c|c|c|}
\hline Agent & Disease & Assay type & Country & Year/ref \\
\hline \multicolumn{5}{|l|}{ Viral } \\
\hline Measles & Measles & HAI & USA & $84^{34}$ \\
\hline \multirow[t]{2}{*}{ Dengue } & Dengue fever & ELISA & Brazil & $91^{35}$ \\
\hline & & ELISA & Thailand & $94^{36}$ \\
\hline Rubella & Rubella & HI, SPIHIT & Thailand & $91^{37}$ \\
\hline \multicolumn{5}{|l|}{ Bacterial } \\
\hline \multirow[t]{3}{*}{ Mycobacterium leprae } & Leprosy & RIA & India & $90^{38}$ \\
\hline & & ELISA & Polynesia & $91^{39}$ \\
\hline & & PA & India & $92^{28}$ \\
\hline Helicobacter pylori & Dyspepsia & ELISA & Australia & $91^{40}$ \\
\hline Brucella sp & Human brucellosis & IgM-ELISA & Spain & $95^{41}$ \\
\hline Treponema pallidum & Syphilis & GPA & England & $98^{42}$ \\
\hline \multicolumn{5}{|l|}{ Protozoan } \\
\hline Plasmodium falciparum & Malaria & ELISA & Venezuela & $89^{43}$ \\
\hline \multirow[t]{3}{*}{ Toxoplasm gondii } & Congenital toxoplasmosis & ELISA & USA & $92^{44}$ \\
\hline & & Dye test & England & $94^{45}$ \\
\hline & & ELISA & Denmark & $95^{17}$ \\
\hline Giardia lamblia & Giardia & ELISA & Saudi Arabia & $93^{46}$ \\
\hline \multirow[t]{2}{*}{ Leishmania spp } & Kala-azar & Dot-ELISA & India & $93^{47}$ \\
\hline & Leishmaniasis & PA & India & $95^{48}$ \\
\hline Trypanasoma cruzi & Chagas disease & IFAT, HAI, ELISA & Brazil & $95^{49}$ \\
\hline \multicolumn{5}{|l|}{ Helminthic } \\
\hline Schistosoma haematobium & Bilharzia & ELISA & Somalia & $88^{50}$ \\
\hline Brugia malayi & Filariasis & $\mathrm{IgG}_{4}$-ELISA & Indonesia & $96^{51}$ \\
\hline
\end{tabular}

ELISA, enzyme linked immunosorbent assay; GPA, gelatin particle agglutination; HAI, haemagglutination inhibition assay; IFAT, immunofluorescence antibody test; PA, particle agglutination; RIA, radioimmunoassay; SPIHIT, solid phase immunosorbent haemagglutination inhibition test. 
[1]

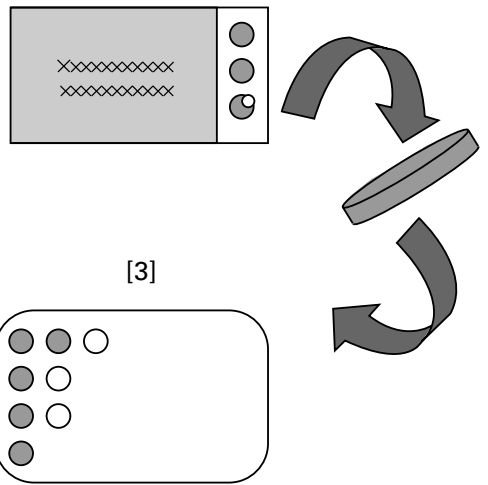

[4]

$[5]$

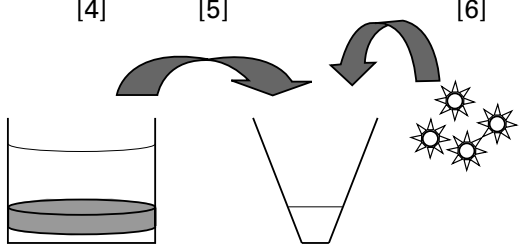

Modified Serodia-HIV gelatin particle agglutination test

[2]

1. Whole blood from a heel prick is blotted onto a Guthrie card.

2. Two $4.7 \mathrm{~mm}$ discs are punched out...

3. .. and placed in a flat bottomed microtitre plate, fig 2 .

4. Plates are incubated overnight at $4^{\circ} \mathrm{C}$ in $170 \mu \mathrm{l}$ of elution buffer, PBS/tween80.

$5.5 \mu \mathrm{l}$ of eluate is added to $20 \mu \mathrm{l}$ of TPPA reagent buffer in a $V$ well microtitre plate.

6. $25 \mu \mathrm{l}$ of a 1:10 dilution of Serodia gelatin particles are added to every well and plates are shaken and left overnight at $\mathrm{RT}^{\circ} \mathrm{C}$ on a vibration free surface, fig 3 .

Figure 1 Procedure for processing dried blood spot samples. RT, room temperature.

This may be particularly valuable for monitoring herd immunity and the extent of vaccine coverage at a time when the eradication of several viruses - for example, poliomyelitis, measles, mumps, and rubella-is in prospect in many parts of the world. The Guthrie card or neonatal DBS provides information on the prevalence of antibody to a pathogen in women of childbearing age, thus giving a more representative indication of the impact within a community than screening blood donors, who are often unrepresentative. Furthermore, within the United Kingdom, coverage of the Guthrie card programme for metabolic screening approaches $100 \%,{ }^{2}$ providing a resource that has almost complete coverage of a specific target population, a rare event in epidemiological studies.

\section{Application of DBS technology}

Following the historical use of DBS to study the prevalence of $\mathrm{HBV},{ }^{19}$ measles, ${ }^{34}$ and

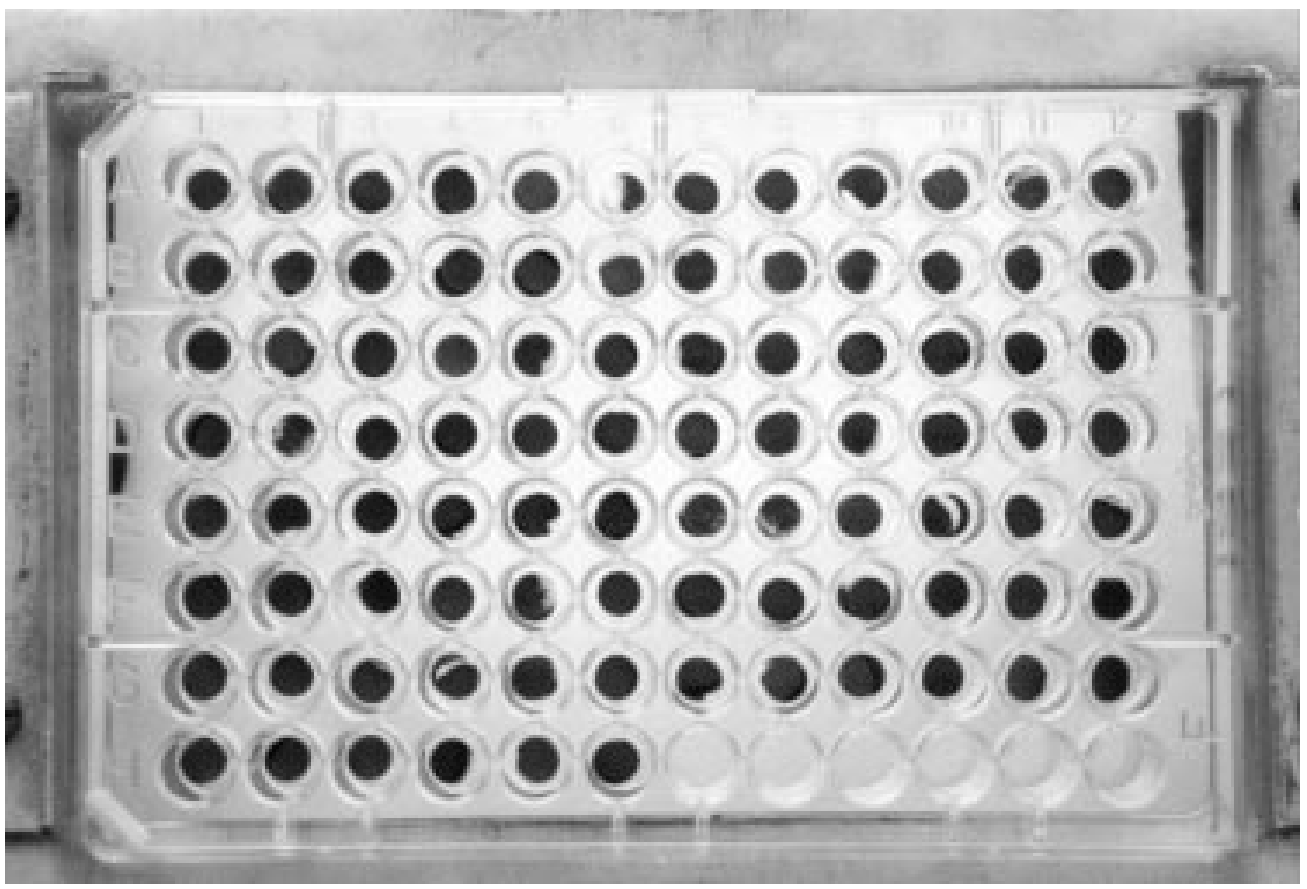

Figure 2 Two dried blood spot samples are punched into the first 90 wells of a flat bottomed pate. 


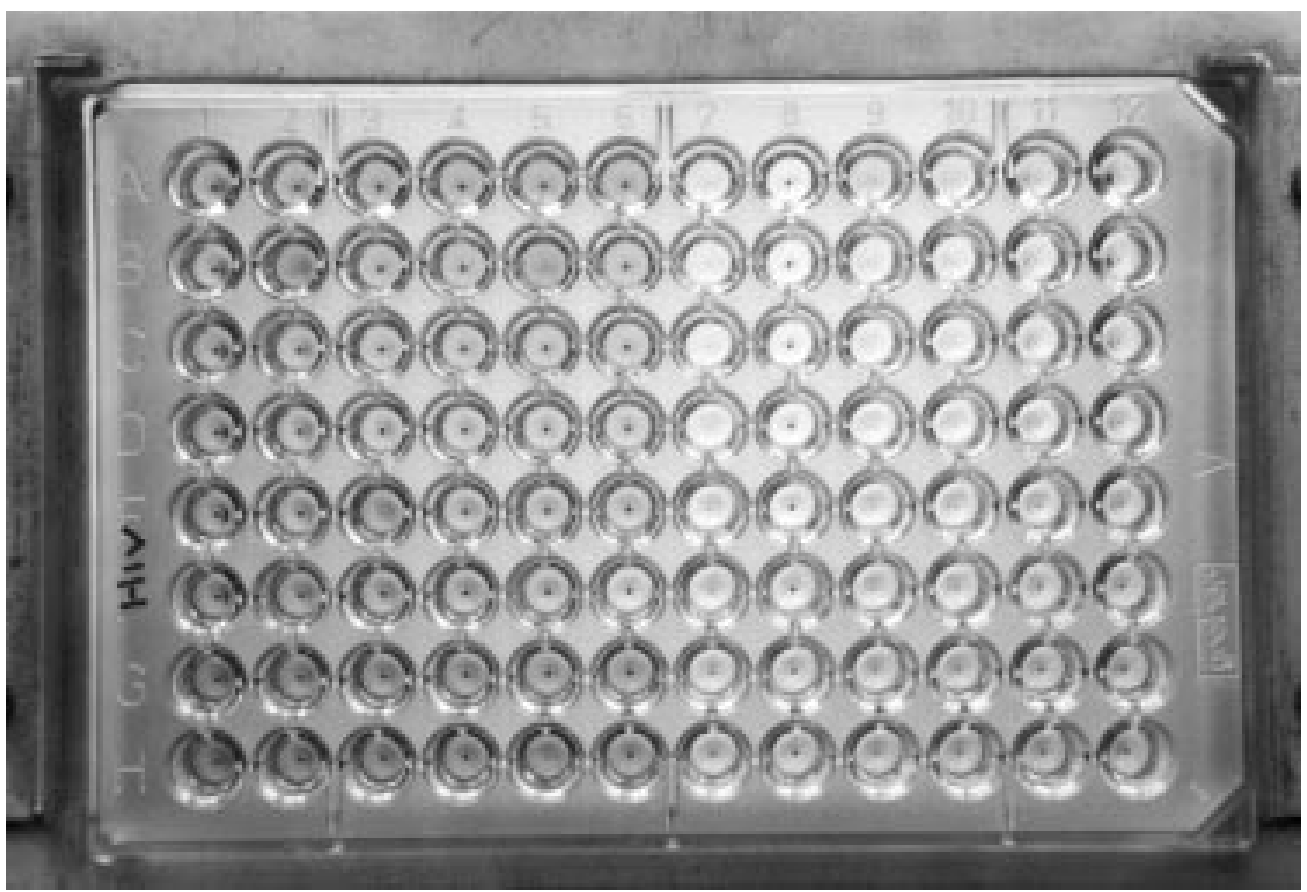

Figure 3 The modified Serodia HIV GPA test. Agglutination in wells B2, E3, B5, and H5 indicates reactivity to HIV-1 specific gelatin particles. In the absence or reactive particles settle at the bottom of the $V$ well. Columns 7-12: initial reactive samples are titrated out by double dilution to end point; column 7: positive serum control (1:64); column 8: negative serum control (< 1:5); column 9: sample B2 (1:64); column 10: sample E3 (1:64); column 11: sample B5 (1:16); column 12: sample H5 (1:8).

rubella, ${ }^{21}$ the feasibility of using similar technology for sentinel surveillance of HIV in the developing world was evaluated..$^{60}$ At the same time the need for an inexpensive and effective means for monitoring the extent of HIV in Europe ${ }^{6263}$ and the USA ${ }^{64}$ was being increasingly recognised.

SURVEILLANCE OF HIV

Initial doubts over the sensitivity and specificity of DBS based compared with serological assays were dispelled by parallel testing of DBS and sera $^{55656}$ which showed $99-100 \%$ concordance. Furthermore extensive studies proved that concerns about the presence of haem in the eluate and adverse storage, for example in tropical conditions, causing false reactions were unfounded. ${ }^{54556768}$

The prevalence of antibodies to HIV-1 in women of childbearing age based on the testing of anonymous DBS obtained from neonates was first reported in the USA in $1988 .{ }^{64}$ Laboratories at the Centers for Disease Control, Atlanta, extended the newborn screening quality assurance programme to include test panels of anti-HIV positive and negative DBS, which were distributed throughout the USA and overseas. ${ }^{69}$ Subsequently in 1990, after a successful pilot study, anonymous neonatal testing was introduced in the United Kingdom and a similar quality control programme was made available by the Central Public Health laboratory in London. ${ }^{70}$

Since the inception of anonymous screening at Great Ormond Street Hospital for Children and the Institute of Child Health, over 1.2 million DBS have been tested enabling accurate data to be obtained about the prevalence of
HIV-1 in mothers in the Thames region over an eight year period. ${ }^{12}$

HUMAN T CELL LEUKAEMIA/LYMPHOMA VIRUS HTLV-I has been recognised as the causal agent of adult $T$ cell leukaemia, tropical spastic paraparesis, myelopathy, and uveitis. Transmission may occur by several means including breast feeding and through contaminated blood. In order to assess the extent of HTLV-I infection in women of child bearing age in London, a modified gelatin particle assay costing $10 \mathrm{p}$ per test was used to screen over 10000 DBS obtained from neonates. ${ }^{13}$ The prevalence rate was $0.05 \%$, lower than that reported $(0.21 \%$ to $0.27 \%)$ in antenatal surveys from other London districts but higher than the rates reported in blood donors $(0.004 \%$ to $5 \%)$, reviewed in $1996 .^{71}$ The technique has also been successfully applied to screen mothers and children in South Africa. ${ }^{14}$

\section{TOXOPLASMA GONDII}

Toxoplasma gondii is recognised to be a major cause of congenital infection, which may result in mental retardation and late onset chorioretinitis. However, the prevalence of infection varies widely in different European countries, ranging from less than $15 \%$ in Scandinavia and England to more than $70 \%$ in France. ${ }^{72}$ This has led to differing opinions about the need for antenatal screening.

A modified latex test costing less than $5 \mathrm{p}$ per test has been used for extensive surveys to determine the maternal prevalence of antibodies in London. The results of screening 12902 neonatal DBS showed the rate in United Kingdom born women in inner London was 
$12.5 \%,{ }^{16}$ similar to the rate of $13.3 \%$ obtained when 3768 sera from a comparable group were screened by EIA. ${ }^{72}$ Recently, neonatal Guthrie cards were used to screen 16035 specimens collected during 1995, representing 33\% of the live births registered in Eire that year. The results showed a prevalence ranging from $20.3 \%$ in urban Dublin to $45 \%$ in a rural area, Louth, and an overall prevalence of $25 \% .^{18}$ This compares with a prevalence of $31 \%$ in sera collected between 1980 and 1986 from women born in Eire. ${ }^{72}$

\section{DETECTION OF NUCLEIC ACID IN DBS}

The potential for the use of DBS for the detection of nucleic acid was first realised in 1987, when DNA was released from the filter paper by microextraction for the purposes of newborn screening. ${ }^{73}$ The molecular analysis of DNA obtained from neonates has enabled detection of genetic mutations responsible for, among others, cystic fibrosis, ${ }^{74} 75$ oncogenesis, ${ }^{76}$ markers of type 1 diabetes, ${ }^{77}$ and $\alpha$ thalassaemia. ${ }^{78}$

The stability of DNA has made it possible to apply PCR to detect proviral HIV DNA sequences several months after sample collection, even when DBS had been held at room temperature.$^{79}$ Recent studies have shown that HIV DNA and RNA can be recovered after five years without refrigeration, ${ }^{80}$ which may provide the potential for retrospective surveys and the use of stored Guthrie cards as DNA banks. $^{81}$

An unexpected benefit of storage is that inhibitors of PCR such as protein, haemoglobin, and iron seem to become increasingly resistant to elution, whereas "fixation" of nucleic acid to the matrix of the filter paper seems to aid stability and does not impair its elution. ${ }^{82}$

The ability to detect HIV proviral DNA in DBS obtained from neonates has been used in several retrospective studies to estimate rates of vertical transmission. ${ }^{83-88}$ However, it has been shown that there are some limitations to the use of Guthrie cards. For example, proviral DNA could only be detected in $50 \%$ of infected children aged less than 10 days, the time at which samples are generally collected from neonates in the United Kingdom. In contrast, virtually all infected children were identified when DBS obtained from infants aged one month were tested. ${ }^{54}$ Amplification of DNA has enabled sequences encoding the gag and env regions to be studied, providing valuable epidemiological data about the geographical distribution of HIV subtypes. ${ }^{88} 89$ Quantification of HIV-1 RNA using kit based amplification technology in the form of NASBA and Amplicor-HIV has been described using dried plasma spots collected on filter paper. ${ }^{80}$ PCR methods have also been developed to detect proviral sequences from DBS obtained from neonates infected with cytomegalovirus ${ }^{90}$ and patients infected with HTLV-I. ${ }^{91}$

\section{Concluding remarks}

Significant increases in the sensitivity and specificity of diagnostic tests have allowed the detection of microquantities of antibodies in saliva, dried blood spot samples, and urine. These samples herald a move away from invasive techniques and the need to obtain large volumes of blood. Dried blood spot samples have an advantage over saliva in that the quality of the sample is less variable and transport and storage is comparatively simple. Application of the techniques described above is ideally suited to surveillance in countries with limited resources and in those participating in large anonymous epidemiological surveys. The ease of transport can ensure effective quality control measures are put in place, highlighted by the success of the quality assurance programme at the Centers for Disease Control, Atlanta, in the shipment of anti-HIV-1 positive and negative DBS to international participants involved in newborn anonymous HIV screening programmes. ${ }^{69}$

Guthrie cards have been collected and stored for many years and provide the potential to perform numerous serological and genetic studies. This has stimulated debate as to who should have access to this material and how the use of such a unique resource can be maximised.

1 Guthrie R, Susi A. A simple phenylalanine method for detecting phenylketonuria in large populations of newborn infants. Pediatrics 1963;32:338-43.

2 Smith I, Cook B, Beasley M. Review of neonatal screening programme for phenylketonuria. BMF 1991;303:333-5.

3 Levy H. Newborn screening. In: Avey M, Taeusch H, eds. Levy H. Newborn screening. In: Avey M, Taeusch H, eds.
Schaffer's diseases of the newborn, 5 th ed. Philadelphia: WB Schaffer's diseases of the
Saunders, 1984:60-4.

4 Henderson SJ, Fishlock K, Horn MEC, et al. Neonatal creening for haemoglobin-variants using filter paper-drie blood specimens. Clin Lab Haematol 1991;13:327-34.

5 Dezateux C. Evaluating newborn screening programmes based on dried blood spots: future challenges. $\mathrm{Br}$ Med Bull 1998;54:877-90

6 Spencer K, Macri JN, Carpenter P, et al. Stability of intact chorionic-gonadotropin (hCG) in serum, liquid wholeblood and dried whole-blood filter-paper spots-impact on screening for Down syndrome by measurement of free beta-hCG subunit. Clin Chem 1993;39:1064-8.

7 Gay EC, Cruickshanks KJ, Chase HP, et al. Accuracy of a filter paper method for measuring glycosylated hemoglobin. Diabetes Care 1992;15:108-10.

8 Henderson LO, Powell MK, Hannon WH, et al. An evaluation of the use of dried blood spots from newborn screening for monitoring the prevalence of cocaine use among childbearing women. Biochem Mol Med 1997;61:143-51.

9 Gwinn M, Redus MA, Granade TC, et al. HIV-1 serologic test-results for one million newborn dried-blood specimens - assay performance and implications for screening. F AIDS 1992;5:505-12.

10 Grady GF. HIV mass screening of infants and mothers: historical, technical, and practical issues. Acta Paediatr Suppl 1994;400:39-42.

11 Tappin DM, Girdwood RW, Follett EA, et al. Prevalence of maternal HIV infection in Scotland based on unlinked anonymous testing of newborn babies. Update. Scot Med $\mathcal{F}$ 1993;38:16-17.

12 Nicoll A, McGarrigle C, Brady AR, et al. Epidemiology and detection of HIV-1 among pregnant women in the United Kingdom: results from national surveillance 1988-96. BMF 1998;316:253-8.

13 Parker SP, Taylor MB, Ades AE, et al. Use of dried blood spots for the detection and confirmation of HTLV-I specific antibodies for epidemiologic purposes. I Clin Pathol 1995;48:904-7.

14 Taylor MB, Parker SP, Crewe-Brown HH, et al. Seroepidemiology of HTLV-I in relation to that of HIV-1 in the Gauteng region, South Africa, using dried blood spots on filter papers. Epidemiol Infect 1996;117:343-8.

15 Parker SP, Cubitt WD, Ades AE. A method for the detection and confirmation of antibodies to hepatitis $\mathrm{C}$ virus in dried blood spots. F Virol Methods 1997;68:199-205.

16 Parker SP, Cubitt WD. Modified latex agglutination test for antibodies to Toxoplasma gondii in eluates from Guthrie cards [published erratum appears in $\mathcal{F}$ Clin Pathol 1993;46: 192]. F Clin Pathol 1992;45:907-9.

17 Lebech M, Petersen E. Detection by enzyme immunosorbent assay of Toxoplasma gondii IgG antibodies in dried blood spots on PKU0-filter paper from newborns. Scand $\mathcal{F}$ Infect Dis 1995;27:259-63.

18 Cafferkey M, Lennon B, Johnson Z, et al. Seroprevalence of antibody to Toxoplasma gondii in Irish women of 
child-bearing age. In: Holland C, ed. Modern perspectives in demy, 1997:39-44.

19 Farzadegan H, Noori K, Ala F. Detection of hepatitis B surface antigen in blood and blood products on filter paper. Lancet 1978;i:362-3.

20 Villa E, Cartolari R, Bellentani S, et al. Hepatitis-B virus markers on dried blood spots - a new tool for epidemiological research. $\mathcal{F}$ Clin Pathol 1981;34:809-12.

21 Vejtorp M, Leerhoy J. Rubella immunoglobulin-G antibody detection by elisa using capillary blood-samples collected on filter-paper and in microtainer tubes. Acta Pathol Microbiol Scand Sect B-Microbiol 1981;89:369-70.

22 Zoulek G, Burger P, Deinhardt F. Markers of hepatitis virus-A and virus-B - direct comparison between whole serum and

23 Jensen TG, Whittle $\mathrm{H}$, Mordhorst $\mathrm{CH}$, et al. Trials of Edmonston-Zagreb measles vaccine in Guinea-Bissau Edmonston-Zagreb measles vaccine in Guinea-Bissau Edmonston-Zagreb strain at $4-8$ months versus vaccinaEdmonston-Zagreb strain at $4-8$ months versus vaccina-
tion with Schwarz strain at $9-12$ months of age. Vaccine tion with Schwarz

24 Grandolfo ME, Medda E, Novello F, et al, and study group. Seroepidemiological evaluation of 1989-91 mass vaccination campaigns against measles, in Italy. Epidemiol Infect 1998;121:645-52.

25 Condorelli F, Scalia G, Stivala A, et al. Detection of immunoglobulin-G to measles-virus, rubella-virus, and mumps-virus in serum samples and in microquantities of whole-blood dried on filter-paper. 7 Virol Methods 1994;49: 25-36.

26 Condorelli F, Stivala A, Gallo R, et al. Use of a microquantity enzyme immunoassay in a large scale study of measles,
mumps and rubella immunity in Italy. Eur $\mathcal{f}$ Clin Microbiol Infect Dis 1998;1:49-52.

27 Navas E, Bayas JM, Bruguera M, et al. The efficacy of the prevaccination detection of antibodies against hepatitis-A in the hepa

28 Sekar B, Anandan D. Evaluation of Mycobacterium-leprae particle agglutination-test, using eluates of filter-paper blood spots. Lepr Rev 1992;63:117-24.

29 Nikoletti S. Measurement of diphtheria and tetanus antitoxin in blood samples collected on filter paper disks. Epidemiol Infect 1994;112:161-70.

30 Hong HA, Ke NT, Nhon TN, et al. Validation of the combined toxin-binding inhibition test for determination of neutralising antibodies against tetanus and diptheria toxins in a vaccine field study in Vietnam. Bull WHO 1997; 74:275-82.

31 Zicker F, Smith PG, Luquetti AO, et al. Mass-screening for Trypanosoma-cruzi infections using the immunofluorescence, ELISA and hemagglutination tests on serum cence, ELISA and hemagglutination tests on serum
samples and on blood eluates from filter-paper. Bull WHO samples and on bloc

32 Coltorti E, Guarnera E, Larrieu E, et al. Seroepidemiology of human hydatidosis - use of dried blood-samples on filter-paper. Trans R Soc Trop Med Hyg 1988;82:607-10.

33 Kenny JV, MacCabe RJ. Sero-epidemiology of hydatid disease in the non-intervention area of north-east Turkana. Ann Tropical Med Parasitol 1993;87:451-7.

34 Wassilak S, Bernier R, Herrmann K, et al. Measles seroconfirmation using dried capillary blood specimens in filter paper. Pediatr Infect Dis 1984;3:117-21

35 Vazquez S, Fernandez R, Llorente C. Use of filter-paper strips on an ELISA inhibition test for serologic studies on dengue. Revista Inst Med Trop Sao Paulo 1991;33:309-11.

36 Ruangturakit S, Rojanasuphot S, Srijuggravanvong A, et al. Storage stability of dengue IgM and IgG antibodies in whole blood and serum dried on filter paper strips detected whole blood and serum dried on filter paper strips detected by ELISA

37 Punnarugsa V, Mungmee V. Detection of rubella virus mmunoglobulin $\mathrm{G}$ (IgG) and IgM antibodies in whole blood on Whatman paper: comparison with detection in sera. F Clin Microbiol 1991;29:2209-12.

38 Patil SA, Ramu G, Sinha S, et al. Screening of anti-M leprae antibodies in the blood-samples eluted from filter-paper blood blots. Int $\mathcal{F}$ Leprosy 1990;58:123-6.

39 Chanteau S, Cartel JI, Boutin JP, et al. Evaluation of gelatin particle agglutination assay for the detection of anti-PGLI antibodies - comparison with ELISA method and applicability on a large-scale study using blood collected on filterpaper. Leprosy Rev 1991;62:255-61.

40 Huang Z, Dwyer B, Kaldor J. Helicobacter-pylori serology using specimens collected on filter-paper. 7 Clin Pathol 1991;44:167-9.

41 Takkouche B, Iglesias J, Alonso-Fernandez JR, et al. Detection of Brucella antibodies in eluted dried blood: a validation study. Immunol Lett 1995;45:107-8.

42 Coates G, Guarenti L, Parker S, et al. Evaluation of the sensitivity and specificity of a Treponema pallidum dried blood spot technique for use in the detection of syphilis. Trans R Soc Trop Med Hyg 1998;92:44.

43 Perez HA, Bolivar J. The feasibility of filter-paper collected blood for the serodiagnosis of malaria. Mem Inst Oswaldo Cruz 1989;84:587-8.

44 Hsu HW, Grady GF, Maguire J, et al. Newborn screening for congenital Toxoplasma infection: five years experience in Massachusetts, USA. Scand $\mathcal{F}$ Infect Dis 1992;S84:5964.

45 Patel B, Holliman RE. Antibodies to Toxoplasma-gondii in eluates from filter-paper blood specimens. Br $\mathcal{F}$ Biomed $\mathrm{Sci}$ 1994;51:104-8.
46 Altukhi MH, Ackers JP, Alahdal MN, et al. Enzyme-linkedimmunosorbent-assay for the detection of anti-Giardia pecific immunoglobulin-G in filter-paper blood-samples. Trans R Soc Trop Med Hyg 1993;87:36-8.

47 Gupta S, Srivastava JK, Ray S, et al. Evaluation of enzymelinked immunosorbent assay in the diagnosis of kala-azar in Malda district (West Bengal). Ind 7 Med Res Sect A Infect Dis 1993;97:242-6.

48 Addy M, Nandy A. Evaluation of direct agglutination-test in the diagnosis of subclinical kala-azar and lymphatic leishmaniasis. F Protozool Res 1995;5:1-9.

49 Machadocoelho GLL, Vitor RWD, Chiari CD, et al. Validity of serology for American trypanosomiasis with eluates from filter-paper. Mem Inst Oswaldo Cruz 1995;90:59-64.

50 Evengard B, Hagi H, Linder E. A filter-paper technique for the detection of IgG and IgM class schistosome-specific antibodies in an endemic area. Ann Trop Med Parasitol 1988;82:307-9.

51 Terhell AJ, Haarbrink M, Abadi K, et al. A filter paper technique for the detection of anti-filarial IgG4 in lymphatic filariasis. Trans R Soc Trop Med Hyg 1996;90:196-8.

52 Williamson J. The utility of bloodspot technologies in low income technologies. In: Improved care of the diseases of childhood. London: Centre for International Child Health, 1997.

53 Knudsen R, Slazyk W, Richmond J, et al. Guidelines from the Centers of Disease Control and Prevention for the shipment of dried blood spot specimens. Washington DC: US Department of Health and Human Services, 1993:1-4.

54 Behets F, Kashamuka M, Pappaioanou M, et al. Stability of human-immunodeficiency-virus type- 1 antibodies in whole-blood dried on filter-paper and stored under various tropical conditions in Kinshasa, Zaire. 7 Clin Microbiol 992;30:1179-82.

55 Hannon H, Behets F, Quinn TC. Stability of human immunodeficiency virus type 1 antibodies in whole bloodmpregnated filter papers under various tropical conditions. F Clin Microbiol 1993;31:765-6.

56 Vandenakker R, Kooy H, Vandermeyden HP, et al. Recovery of HIV antibodies in eluates from plasma and erythrocytes AIDS 1990;4:90-1.

57 Evengard B, Vonsydow M, Ehrnst A, et al. Filter-paper sampling of blood infected with HIV-effect of heat on pling of blood infected with HIV-effect of heat on

58 Resnisk L, Veren K, Salahuddin S, et al. Stability and inactiResnisk L, Veren K, Salahuddin S, et al. Stability and inacti-
vation of HTLV III/LAV under clinical and laboratory environments. $7 A M A$ 1986;255:1887-91.

59 Bond WW, Favero MS, Petersen NJ, et al. Survival of hepatitis B virus after drying for one week. Lancet 1981;i:550-1.

60 Farzadegan H, Quinn T, Polk B. Detecting antibodies to human immunodeficiency virus in dried blood on filter papers. F Infect Dis 1987;155:1073-74.

61 Arya SC. Testing for AIDS on samples of dried blood prepared on filter papers. Vaccine 1988;6:210

62 Varnier OE, Lillo FB, Reina S, et al. Whole-blood collection on filter-paper is an effective means of obtaining samples or human immunodeficiency virus-antibody assay. $\mathcal{F} A I D S$ 1988;4:131-6.

63 Lindhardt BO, Bygbjerg IC, Ulrich K, et al. Detection of antibodies to human immunodeficiency virus (HIV) in eluates from whole-blood impregnated filter-paper disks. $\mathcal{F}$ Virol Methods 1987;18:73-7.

64 Hoff R, Berardi V, Weiblen B, et al. Seroprevalence of human immunodeficiency virus among childbearing women: estimation by testing samples of
borns. $N$ Engl f Med 1988; 318:525-30.

65 Fortes P, Menitove J, Ross A, et al. Evaluation of blood collected on filter-paper for detection of antibodies to human immunodeficiency virus type-1. F Clin Microbiol 1989;27: 1380-1.

66 Beebe JL, Briggs LC. Evaluation of enzyme-linked immunoassay systems for detection of humanimmunodeficiency-virus type- 1 antibody from filter-paper disks impregnated with whole-blood. 7 Clin Microbiol 1990; 28:808-10.

67 Arya SC. Stability of human immunodeficiency virus type 1 antibodies in whole blood impregnated filter papers under various tropical conditions. F Clin Microbiol 1993;31:765-6.

68 Evengard B, Ehrnst A, Vonsydow M, et al. Effect of heat on extracted HIV viral infectivity and antibody-activity using the filter-paper technique of blood-sampling. AIDS 1989; 3:591-5.

69 Hannon W, Lewis D, Jones W, et al. A quality assurance program for human immunodeficiency virus seropositivity screening of dried blood spot specimens. Infect Con Hosp Epidemiol 1989;10:8-13.

70 Parry JV, Mortimer PP, Nicoll AG. Performance assessment of neonatal dried blood spot testing for HIV antibody. Commun Dis Rep CDR Rev 1992;2:R128-30.

71 The HTLV European Research Network. Seroepidemiology of the human T-cell leukaemia/lymphoma viruses in Europe. F AIDS 1996;13:68-77.

72 Gilbert RE, Tookey PA, Cubitt WD, et al. Prevalence of toxoplasma IgG among pregnant women in west London 306: 185 .

73 McCabe ERB, Huang SZ, Seltzer WK, et al. DNA microextraction from dried blood spots on filter-paper blotterspotential applications to newborn screening. Hum Genet 1987;75:213-16.

74 Spence WC, Paulusthomas J, Lisanti J, et al. Confirmation of cystic-fibrosis in a newborn screening-program by 
molecular analysis of DNA from dried filter-paper blood

75 Hopfer SM, Makowski GS, Davis EL, et al. Detection of Hopfer SM, Makowski GS, Davis EL, et al. Detection of
cystic fibrosis DeltaF508 mutation by anti-doublestranded DNA antibody. Ann Clin Lab Sci 1995;25:47584.

76 Fishbein WN, Kirsch IR. Detection of chromosome-7 inversions in peripheral-blood specimens dried on filterpaper as a population screen for potential oncogenesis and for exposure to environmental genotoxins [abstract]. Clin Res 1993;41:A271.

77 Sjoroos M, Iitia A, Ilonen J, et al. Triple-label hybridization assay for type-1 diabetes-related HLA alleles. Biotechniques 1995;18:870-7.

78 Harada F, Ireland JH, Hsia YE, et al. Anti-zeta antibody screening for alpha-thalassemia using dried filter paper blood. Biochem Med Metab Biol 1994;51:80-4.

79 Cassol S, Salas T, Gill MJ, et al. Stability of dried blood spot specimens for detection of human immunodeficiency virus 30:3039-42.

80 Cassol S, Gill MJ, Pilon R, et al. Quantification of human immunodeficiency virus type 1 RNA from dried plasma spots collected on filter paper. F Clin Microbiol 1997;35 2795-801.

81 McEwen J, Reilly P. Stored Guthrie cards as DNA 'banks.' Am F Human Genet 1994;55:196-200.

82 Makowski GS, Davis EL, Hopfer SM. The effect of storage on Guthrie cards: implications for deoxyribonucleic acid amplification. Ann Clin Lab Sci 1996;26:458-69.

83 Cassol S, Butcher A, Kinard S, et al. Rapid screening for early detection of mother to child transmission of human immunodeficiency virus type 1 . 7 Clin Microbiol 1994;32: 2641-5.
84 Comeau AM, Pitt J, Hillyer GV, et al. Early detection of human immunodeficiency virus on dried blood spot specimens: sensitivity across serial specimens. 7 Pediatr 1996;129:111-18

85 Nyambi PN, Fransen K, Debeenhouwer H, et al. Detection of human-immunodeficiency-virus type-1 (HIV-1) in heel prick blood on filter-paper from children born to 2858-60.

86 Kunisada T, Ando S, Saito K, et al. Detection of human immunodeficiency virus-1 nucleic-acid on inactivated filter-paper disks by polymerase chain-reaction and microtiter plate assay. Microbiol Immunol 1994;38:649-54.

87 Yourno J. Direct polymerase chain-reaction for detection of human-immunodeficiency-virus in blood spot residues on filter-paper after elution of antibodies-an adjunct to serological surveys for estimating vertical transmission rates lon mong human-immunodeficiency-virus an (

$\mathrm{R}$, et al. Rapid method for screening dried blood spot samples on filter paper for human immunodeficiency virus type 1 DNA. f Clin Microbiol 1999;37:350-3.

89 Cassol S, Weniger BG, Babu PG, et al. Detection of HIV type 1 env subtypes A, B, C, and E in Asia using dried blood spots: a new surveillance tool for molecular epidemiology. AIDS Res Hum Retroviruses 1996;12:1435-41.

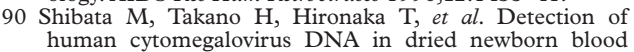
filter-paper. $\mathcal{F}$ Virol Methods 1994;46:279-85.

91 Noda S, Eizuru Y, Minamishima Y, et al. Detection of human T-cell lymphotropic virus type 1 infection by the polymerase chain reaction using dried blood specimens on filter papers. F Virol Methods 1993;43:111-22. 